\title{
Effect of Dietary Supplementation with Diatomaceous Earth on Egg Quality Traits in Hens Raised on Deep Litter
}

\author{
Robert Alex Isabirye, Savino Biryomumaisho, James Acai-Okwee, Samuel Okello, \\ and George William Nasinyama
}

\begin{abstract}
The study was conducted to investigate the effect of dietary diatomaceous earth (DE) on egg quality traits in deep litter hens. A total of 280 Lohmann Brown pullets were at 20 weeks of age divided into 4 groups. Three groups were fed on one of the three experimental diets supplemented with $2 \%, 3 \%$ or $4 \%$ DE, while the fourth group was fed on a control diet without DE supplementation. Each group had seven replicates of 10 birds. One egg was collected randomly per replicate (for a total of 7 eggs per group), weighed and determined for: yolk weight, albumen weight, eggshell weight, eggshell thickness, specific gravity, albumen height, yolk height, yolk colour and Haugh unit. Findings showed that DE supplementation resulted into significant $(p<0.05)$ increase in eggshell weight and yolk height. Dietary supplementation with DE in the current study was, however, not effective on other egg quality parameters such as on eggshell weight percentage, egg specific gravity, yolk colour and Haugh unit. However, results of the study also showed that DE supplementation improved significantly $(p<0.05)$ egg quality especially by improving viscosity as flocks grew older as compared to younger flocks. Further research should focus on the effect of dietary DE on eggshell and bone strength of layer birds. Research should also explore the interactions among the minerals found in DE (e.g. calcium, phosphorus and magnesium) and how these interactions affect egg quality in laying hens.
\end{abstract}

Index Terms - Dietary supplementation, Diatomaceous earth, Egg quality traits, Hens.

\section{INTRODUCTION}

Diatomaceous earth (DE) is the fossilized remains of diatom shells [1]. The benefits of DE in animal production are numerous and include but not limited to health improvement; controlling internal and external parasites; and growth enhancement among other benefits [2]. Diatomaceous earth has also found use as a feed additive where it serves as an anticaking agent as well as controlling mycotoxins [3].

The demand for safe and ethical production of food is increasing each day. This has prompted producers in many countries to put more emphasis on organically produced animal products including organic poultry eggs and other poultry products [4], [5]. In organic farming, the routine use of prophylactic medications is not allowed. Natural products that are organic in nature such as DE need to be promoted to avoid the hazard resulting from the use of synthetic drugs in animal production that lead to residues in animal products posing a health hazard to consumers [6]. Diatomaceous earth has been

Published on November 30, 2020.

Robert Alex Isabirye, Mukono Zonal Agricultural Research and Development Institute, National Agricultural Research Organization; and College of Veterinary Medicine, Animal Resources \& Biosecurity, Makerere University, Uganda.

(e-mail: raisabirye ${ }^{@ y a h o o . c o m) ~}$ recently emphasized as an alternative to synthetic drugs in treatment of livestock diseases [7].

The economic losses due to cracked and damaged eggs account for 6 to $8 \%$ of the total egg production [8]-[10]. A weak, damaged or cracked eggshell can be a quick pathway for microorganisms to reach the inside of the egg leading to deterioration of its quality (ibid). High breaking strength of eggshell and absence of shell defects are paramount in safeguarding eggs against penetration of pathogenic bacteria such as Salmonella sp. On the other hand, eggshell quality attributes play a key role since only eggs having intact shells are taken for hatching or for table use

Nutritional factors for example mineral balance are crucial in maintaining good quality eggshell, so supplementation with bioavailable minerals responsible for the formation of eggshell can be a key strategy [11]. Eggshell quality, therefore, is one of the most important aspects in the poultry industry since it has a big influence on the economics, especially profitability of egg production and hatchability [12]. Therefore, ensuring eggshell quality is the surest way of increasing the number of eggs produced from each hen. Eggshell thickness is hence, one of the major egg quality parameters to consider.

Egg shell quality decreases as the hen grows older [13], [14]. This is due to an increase in egg weight without an increase in the amount of calcium carbonate deposited in the shells. This usually leads to high incidences of cracked eggs towards the end of the laying period which could even exceed 20\% [15].

Consumers consider colour and viscosity of egg yolk among the key indicators when evaluating egg quality. The egg yolk is made up of $35 \%$ lipids; $16 \%$ proteins; and approx. $0.2 \%$ lipophilic pigments which include carotenoids [16]. The egg yolk components combine to make up the final colour. The diet given to laying hens has a big influence on colour tones which range from light yellow to dark orange [17]. Egg yolk colour is also influenced by carotenoids especially zeaxanthin, lutein and xanthophyls and these have antioxidant effects.

Egg viscosity is a physical indicator and largely depends on age of the egg, storage temperature, the $\mathrm{pH}$ value, specific

Savino Biryomumaisho, College of Veterinary Medicine, Animal Resources \& Biosecurity, Makerere University, Uganda.

James Acai-Okwee, College of Veterinary Medicine, Animal Resources \& Biosecurity, Makerere University, Uganda.

Samuel Okello, College of Veterinary Medicine, Animal Resources \& Biosecurity, Makerere University, Uganda.

George William Nasinyama, Kampala International University, Uganda. 
weight, water content and egg stress. When assessing whole egg viscosity, egg yolk viscosity should be emphasized since it is 8 times greater than the viscosity of egg white [18].

The Haugh unit is a measure of egg protein quality based on the height of its egg white (albumen) [19], [20]. This test was introduced in 1937 by Raymond Haugh. It is an important measure of egg quality, which complements other measures, for example shell thickness and strength [21]. A micrometer is used to determine the albumen height that immediately surrounds the yolk. The height which is correlated with the weight determines the Haugh unit (HU) rating. Hence, the higher the Haugh unit, the better the egg quality. This is based on the fact that fresher higher quality eggs have thicker albumens. Although the Haugh unit determines the protein content and freshness of the egg, its limitation is that it does not measure other vital nutrient contents for example the micronutrients or vitamins present in the egg.

The objective of this research was to assess the effect of varying concentrations of dietary diatomaceous earth on egg quality characteristics in hens raised on deep litter. The quality parameters determined were egg weight, yolk weight, albumen weight, yolk colour, shell thickness, specific gravity, and Haugh unit.

\section{MATERIALS AND MeTHODS}

\section{A. Materials}

\section{Experimental site}

The study was conducted at Mukono Zonal Agricultural Research and Development Institute (MUZARDI), which is one of the institutes under the Uganda National Agricultural Research Organization (NARO). MUZARDI is found in the Lake Victoria Crescent Agro-ecological Zone. The coordinates of Mukono town are $002136 \mathrm{~N}, 324500 \mathrm{E}$ and weather in Mukono is influenced by Tropical Monsoon climate [22].

\section{Source of DE for use in the study}

The DE was mined in Pakwach district (formerly Nebbi district) located at $022713 \mathrm{~N}, 313009 \mathrm{E}$, in Northern Uganda. After mining, the DE was ground into small manageable pieces which were later crushed to powder form (with very tiny particles similar to those of talcum powder) to a particle size $\leq$ $40 \mu \mathrm{m}$ using an electric powered milling machine. The powder was then packaged in $200 \mathrm{~g}$ paper sachets using a special pressurized packaging machine.

\section{Materials, Experimental birds and Management}

Day-old chick pullets from Lohmann Brown strain were purchased from a reputable commercial hatchery. The chicks were brooded at $35^{\circ} \mathrm{C}$ at 1day old and fed on chick and duck mash. The temperatures were reduced gradually until the birds developed enough feathers to keep them warm. At six weeks, the birds were removed from the brooder to the main rearing house and placed on deep litter system. At week 8 , the diet was changed to growers' mash. The environmental temperatures were maintained at $20-22{ }^{\circ} \mathrm{C}$ in accordance with the method described by Skrivan and others [23]. At 17 weeks old, the birds were randomly distributed to four treatment groups. Each treatment had seven replications with 10 birds, for a total of 280 birds in the feeding trial. All the feed ration formulations used in feeding the birds in this study were analyzed for proximate principles as per AOAC 2016 [24] (Table 1).

At 18 weeks of age, the feeding trial was run whereby the hens were fed the formulated diets beginning at 20 weeks to 42 weeks old. The four treatment groups formed are as follows: $\mathrm{A}_{0}$ - birds on a diet without any DE supplementation; $\mathrm{A}_{2}$ - birds on $2 \%$ DE supplemented diet; $\mathrm{A}_{3}$ - birds on $3 \% \mathrm{DE}$ supplemented diet; and $\mathrm{A}_{4}$ - birds on $4 \%$ DE supplemented diet.

TABLE1: NUTRIENT COMPOSITION OF DIETS (BEFORE DE SUPPLEMENTATION)

\begin{tabular}{cccc}
\hline Parameter & $\begin{array}{c}\text { Chick and } \\
\text { duck mash }\end{array}$ & $\begin{array}{c}\text { Growers } \\
\text { mash }\end{array}$ & $\begin{array}{c}\text { Layers } \\
\text { mash }\end{array}$ \\
\hline Moisture $(\%)$ & $7.96 \pm 0.79$ & $8.56 \pm 0.49$ & $8.23 \pm 0.71$ \\
Total ash (\%) & $6.75 \pm 0.86$ & $5.68 \pm 0.54$ & $5.79 \pm 0.70$ \\
Crude protein $(\%)$ & $16.46 \pm 0.77$ & $15.23 \pm 1.01$ & $21.25 \pm 0.91$ \\
Crude fibre $(\%)$ & $4.25 \pm 0.54$ & $5.26 \pm 0.88$ & $5.56 \pm 0.73$ \\
Crude fat $(\%)$ & $2.32 \pm 0.45$ & $2.30 \pm 0.46$ & $4.60 \pm 0.51$ \\
Carbohydrate $(\%)$ & $62.13 \pm 2.91$ & $61.43 \pm 2.36$ & $59.55 \pm 3.0$ \\
Energy $(\mathrm{MJ} / \mathrm{kg})$ & $13.89 \pm 0.23$ & $14.19 \pm 0.16$ & $13.81 \pm 0.23$ \\
\hline
\end{tabular}

Proximate analysis of diet determined according to AOAC (2016). All the diets were analyzed before addition of DE used in feeding trial. (Adopted from Isabirye et al., 2019 ${ }^{1}$ ) [25].

\section{B. Methods}

\section{Determination of egg quality parameters}

Seven eggs (1 egg per replicate) were collected randomly from each treatment group for a total of 28 eggs collected at each of week 24, 32 and week 40. Each egg was weighed, and the following parameters were determined: yolk weight, albumen weight, eggshell weight, eggshell thickness and specific gravity. Other parameters determined were albumen height, yolk height, yolk colour and Haugh unit.

The eggs were weighed one at a time on an electronic balance (Camry Inc.) to the nearest $0.01 \mathrm{~g}$ each time after storage at 24, 30 and at 40 weeks of age of the laying pullets. This was required to ensure maximum accuracy and to minimize errors during measurement. Each weighed egg was carefully broken at its equator (middle part) and the contents run on a flat glass surface measuring $20 \times 20 \mathrm{~cm}$ and weighed $\left(\mathrm{W}_{1}\right)$. The yolk and albumen were then separated using an egg yolk separator and the egg yolk removed. The weight of the albumen was recorded $\left(\mathrm{W}_{2}\right)$. The height of the albumen and yolk were measured by placing each of them in a flat glass bowl carefully and the height was measured using the P6085 spherometer (tripod micrometer) with $0.01 \mathrm{~mm}$ accuracy. The height of the albumen was measured at 3 or 4 locations and averaged.

The weight of the egg yolk was obtained by getting the difference between the weights $\left(\mathrm{W}_{1}-\mathrm{W}_{2}\right)$ [26]. To determine eggshell weight, the empty egg shells were cleaned carefully with distilled water then soaked overnight to remove any adhering albumen, and the egg membrane was removed; eggshells were then dried at room temperature for 48 hours and then weighed using an electronic digital balance.

The proportional weight of the eggshell determined as eggshell weight percentage is the proportion of eggshell weight to total egg weight, expressed as a percent. This was measured 
after removal of the internal membrane of the eggshell. The shells were first washed with distilled water, dried at room temperature for 48 hours and weighed on an electronic digital balance. A precision micrometer (Digimatic micrometer, Series 293-330, Mitutoyo Japan) was used giving accuracy to the nearest $0.01 \mathrm{~mm}$. The measurements were taken at the three regions of the shell of each egg viz. at the large end, the equatorial region, and the small end (middle, broad, and narrow ends) and the mean calculated.

Determination of egg specific gravity was based on the Archimedes' Principle. Seven eggs, different from those used in the above experiments (1 egg per replicate) were collected randomly from each treatment group for a total of 28 eggs collected at each of week 24, 32 and week 40 . The eggs were weighed in air on a digital scale. The weight of water displaced by the egg at $22^{\circ} \mathrm{C}$ was determined by submerging the eggs in a beaker of water on the same scale [27]. The egg specific gravity was determined using the equation:

\section{Specific gravity $=$ Egg weight in air/displaced water weight}

Individual Haugh Unit (HU) score was determined using the egg weight and albumen height (Haugh, 1973). Individual egg Haugh Unit values were calculated using the following formula:

$$
H U=100 \log 10\left(H+7.5-1.7 W^{0.37}\right)
$$

where: $\mathrm{H}=$ Observed height of the albumen in $\mathrm{mm}$.

$\mathrm{W}=$ Weight of egg in grams.

The egg yolk colour was determined according to the Roche Yolk Colour Fan (RYCF) which is acceptable throughout the food chain as a standard for measuring yolk colour due its reliability. This is a scale made up of 14 blades numbered 1 to 14 and joined to form a sheet. Each fan blade contains a colour measured objectively and can therefore be reproduced in the yolk [28]. The egg colour was determined prior to yolk height. Before measuring, egg yolk was separated from egg white and placed on a Petri dish of $50 \mathrm{~mm}$ diameter. All measurements were conducted 3 -fold, and the mean of the 3 values was calculated to give the resultant value.

Data were analyzed by one-way ANOVA as a completely randomized design using the GLM procedure of SAS Institute [29]. Significant differences between treatment means were separated using Duncan's multiple range test, with a $5 \%$ probability $(p<0.05)$.

\section{RESULTS}

The trends in changes in the different egg quality characteristics during the study period are presented in Figure 1 to 4 . In all groups, egg weight increased significantly $(\mathrm{p}<0.05)$ with age of the hens (Fig. 1, and Table 2, 3 and 4). Hens in intervention groups produced eggs heavier than those from control groups in weeks 24 and 40 of age. No significant ( $>0.05)$ differences were noted in egg weights at week 32 .
There was significant difference $(\mathrm{p}<0.05)$ in yolk weights at weeks 24 and 40 of age, but no significant ( $p>0.05$ ) differences were noted at week 32 of age (Fig. 1, and Table 2, 3 and 4). Significant interaction $(\mathrm{p}<0.05)$ between DE supplementation and albumen weight was observed at week 24 of age (Fig. 1, and Table 2, 3 and 4). However, no significant interaction was observed at week 32 and week 40. No significant ( $>0.05)$ effects were found with regard to egg specific gravity, eggshell weight percentage, yolk colour and Haugh unit (Fig. 2 and 3, and Table 2, 3 and 4). At week 32, the eggshell thickness from hens in intervention groups was significantly $(\mathrm{p}<0.05)$ higher than in control diet, but no significant interaction between eggshell thickness and DE supplementation was observed at week 24 and 40 of age (Fig. 3 and Table 2, 3 and 4).

Whereas no significant $(\mathrm{p}>0.05)$ interaction between DE supplementation and shell weight was observed at week 24 , shell weights were significantly $\mathrm{p}<0.05$ ) higher in intervention groups at weeks 32 and 40 of age. The results of this study also depict that significant $(\mathrm{p}<0.005)$ increase in yolk as well as in albumen heights was observed in week 40 of age as compared to weeks 24 and 32. However, DE supplementation did not influence yolk colour score as well as Haugh unit throughout this study (Table 2, 3 and 4 and Fig. 4).

TABLE 2: MEAN VALUES OF EGG QUALITY PARAMETERS AT 24 WEEKS OF AGE

\begin{tabular}{|c|c|c|c|c|c|}
\hline \multirow{2}{*}{ Qualities } & \multicolumn{4}{|c|}{ Level of DE Supplementation (\%) } & \multirow[t]{2}{*}{ p-value } \\
\hline & 0 & 2 & 3 & 4 & \\
\hline Egg weight (g) & $54.26^{\mathrm{b}}$ & $57.08^{\mathrm{a}}$ & $57.91^{\mathrm{a}}$ & $57.66^{\mathrm{a}}$ & $<0.0001$ \\
\hline Yolk weight (g) & $17.32^{\mathrm{b}}$ & $18.56^{\mathrm{a}}$ & $17.56^{\mathrm{b}}$ & $17.18^{\mathrm{b}}$ & 0.0061 \\
\hline Albumen weight (g) & $31.82^{\mathrm{c}}$ & $32.92^{\mathrm{b}}$ & $34.49^{\mathrm{a}}$ & $34.79^{\mathrm{a}}$ & 0.0009 \\
\hline Specific gravity & 1.13 & 1.14 & 1.17 & 1.19 & 0.538 \\
\hline Shell weight (g) & 5.12 & 5.59 & 5.86 & 5.69 & 0.3965 \\
\hline $\begin{array}{l}\text { Shell thickness } \\
(\mathrm{mm})\end{array}$ & 0.38 & 0.45 & 0.47 & 0.51 & 0.6260 \\
\hline $\begin{array}{l}\text { Egg shell weight } \\
\text { percentage }(\%)\end{array}$ & 9.44 & 9.8 & 10.12 & 9.86 & 0.2480 \\
\hline Yolk height (mm) & $1.45^{\mathrm{c}}$ & $1.52^{\mathrm{b}}$ & $1.64^{\mathrm{a}}$ & $1.64^{\mathrm{a}}$ & 0.0352 \\
\hline $\begin{array}{l}\text { Albumen height } \\
(\mathrm{mm})\end{array}$ & 4.76 & 5.35 & 5.7 & 5.8 & 0.3950 \\
\hline Yolk colour & 2.2 & 2.26 & 2.21 & 2.26 & 0.3035 \\
\hline Haugh unit & 76.71 & 72.08 & 74.59 & 75.44 & 0.9962 \\
\hline
\end{tabular}

TABLE 3: MEAN VALUES OF EGG QUALITY PARAMETERS AT 32 WEEKS OF AGE

\begin{tabular}{|c|c|c|c|c|c|}
\hline \multirow{2}{*}{ Qualities } & \multicolumn{4}{|c|}{ Level of DE Supplementation (\%) } & \multirow{2}{*}{ p-value } \\
\hline & 0 & 2 & 3 & 4 & \\
\hline Egg weight (g) & 60.25 & 60.64 & 61.27 & 61.43 & 0.3165 \\
\hline Yolk weight (g) & 17.93 & 19.06 & 19.46 & 19.18 & 0.2887 \\
\hline Albumen weight (g) & 36.83 & 36 & 35.95 & 36.48 & 0.2015 \\
\hline Specific gravity & 1.13 & 1.16 & 1.18 & 1.2 & 0.2354 \\
\hline Shell weight (g) & $5.49^{\mathrm{b}}$ & $5.58^{\mathrm{b}}$ & $5.85^{\mathrm{a}}$ & $5.77^{\mathrm{a}}$ & 0.0047 \\
\hline $\begin{array}{l}\text { Shell thickness } \\
\text { (mm) }\end{array}$ & $0.39^{c}$ & $0.44^{\mathrm{b}}$ & $0.46^{\mathrm{b}}$ & $0.49^{\mathrm{a}}$ & 0.0448 \\
\hline $\begin{array}{l}\text { Egg shell weight } \\
\text { percentage }(\%)\end{array}$ & 9.12 & 9.2 & 9.56 & 9.39 & 0.7712 \\
\hline Yolk height (mm) & $1.45^{\mathrm{b}}$ & $1.62^{\mathrm{a}}$ & $1.64^{\mathrm{a}}$ & $1.64^{\mathrm{a}}$ & 0.0111 \\
\hline $\begin{array}{l}\text { Albumen height } \\
\qquad(\mathrm{mm})\end{array}$ & 4.8 & 5.69 & 5.64 & 5.86 & 0.2635 \\
\hline Yolk colour & 2.07 & 2.06 & 2.16 & 2.2 & 0.8132 \\
\hline Haugh unit & 74.48 & 73.44 & 72.84 & 74.53 & 0.8164 \\
\hline
\end{tabular}


TABLE 4: MEAN VALUES OF EGG QUALITY PARAMETERS AT 40 WEEKS OF

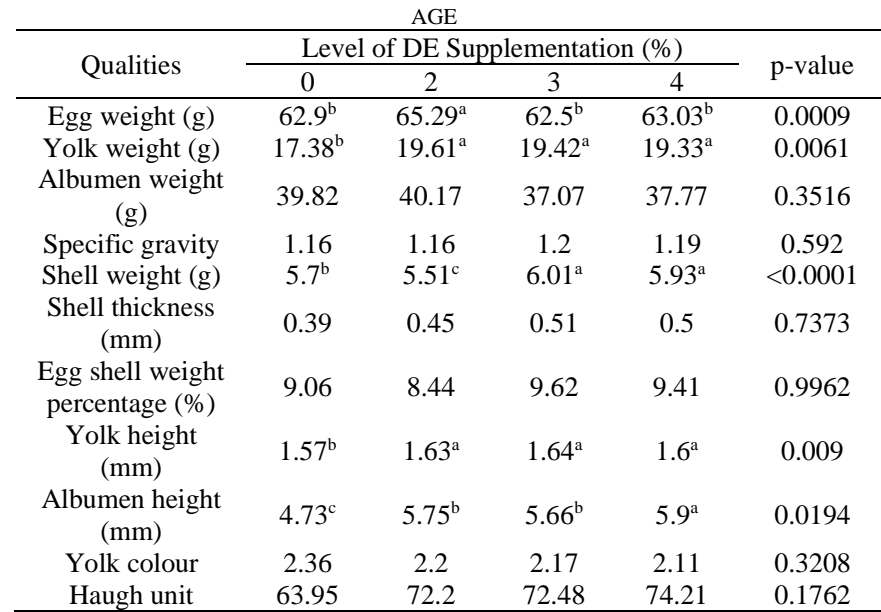

a, b, c Means within a row lacking a common superscript differ significantly $(\mathrm{P}<0.05)$.
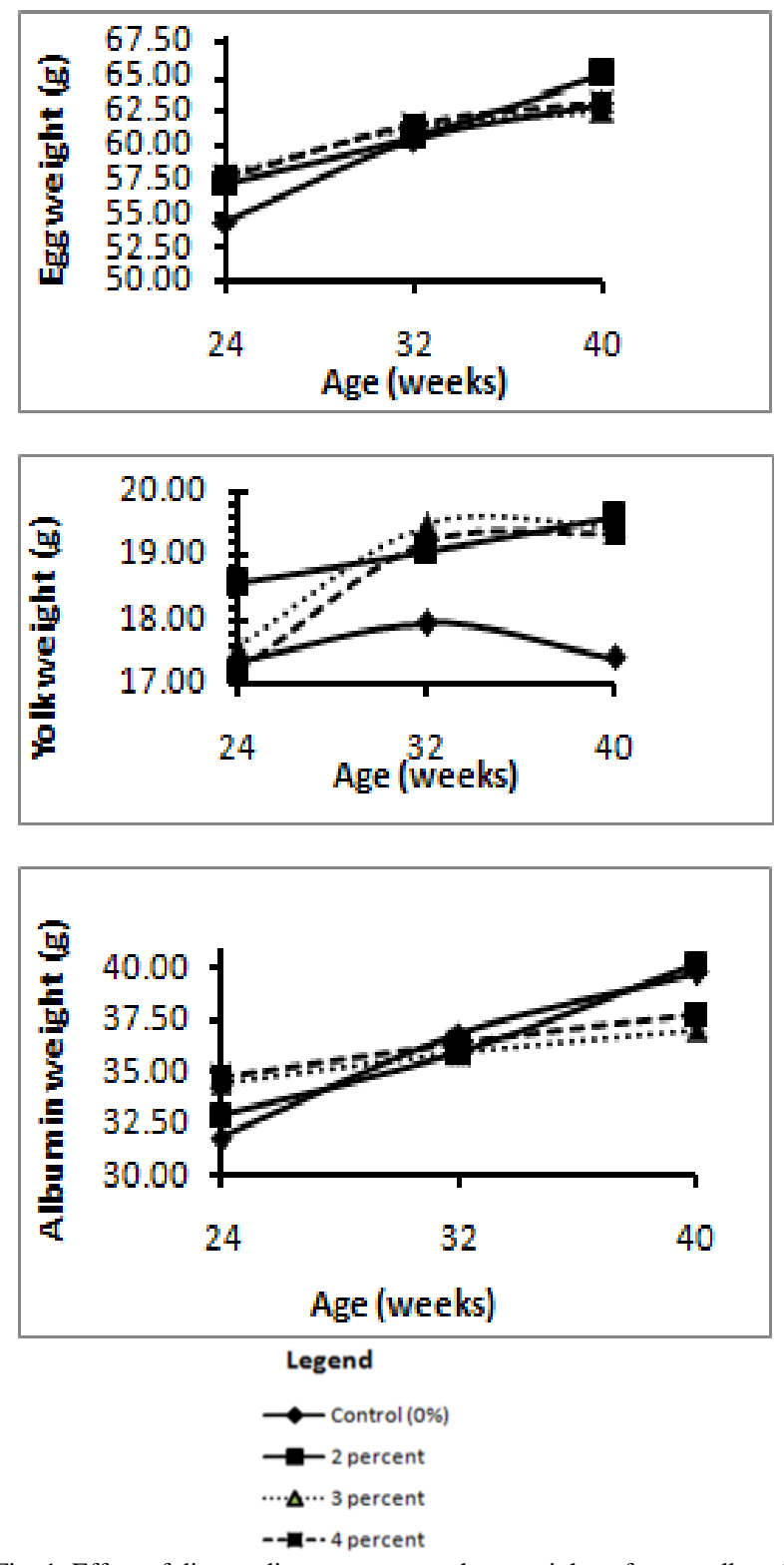

Fig. 1. Effect of dietary diatomaceous earth on weights of egg, yolk and albumen in deep litter raised hens.
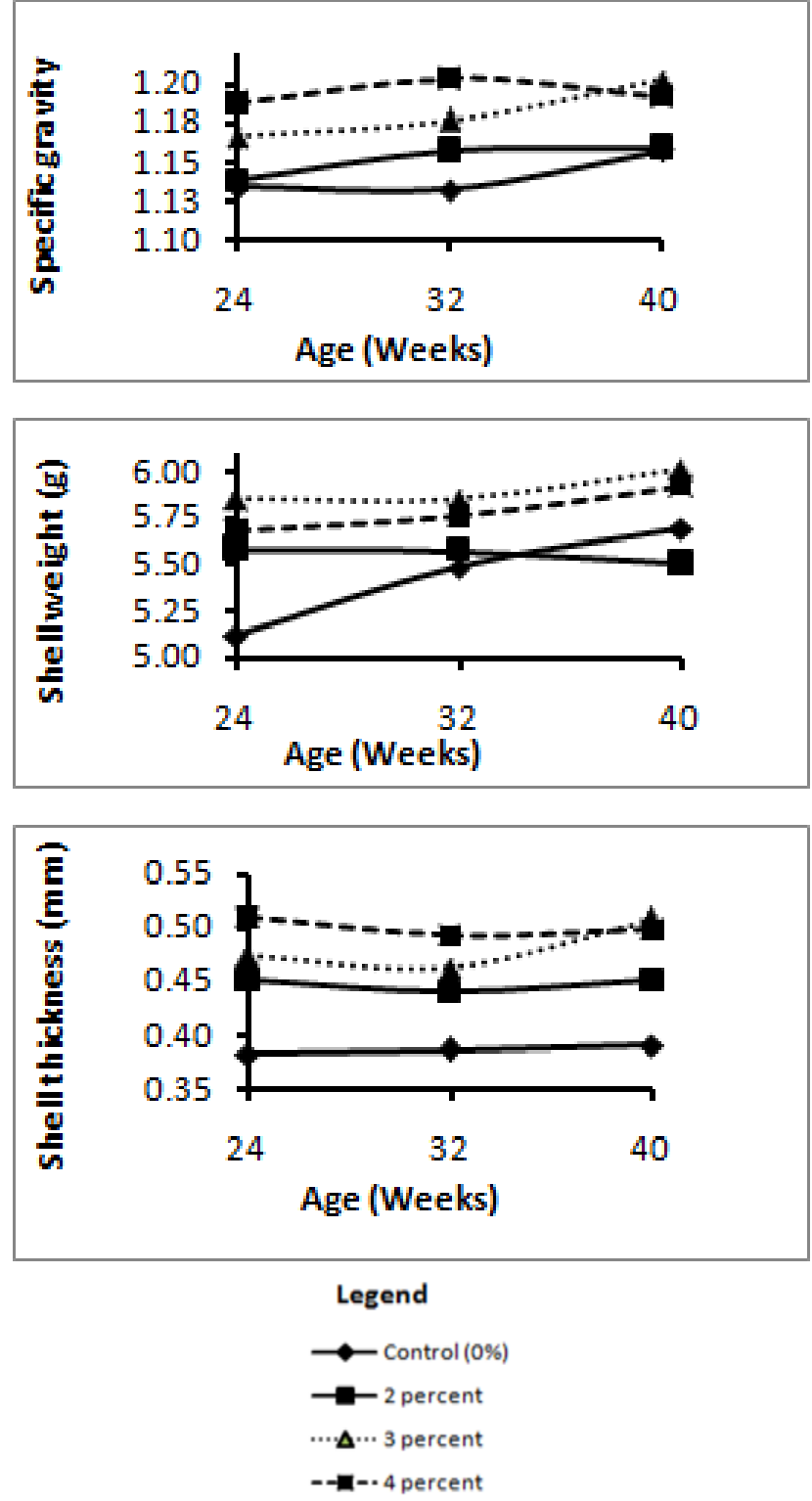

Fig. 2. Effect of dietary diatomaceous earth on specific gravity, shell weight and thickness in deep litter raised hens. 

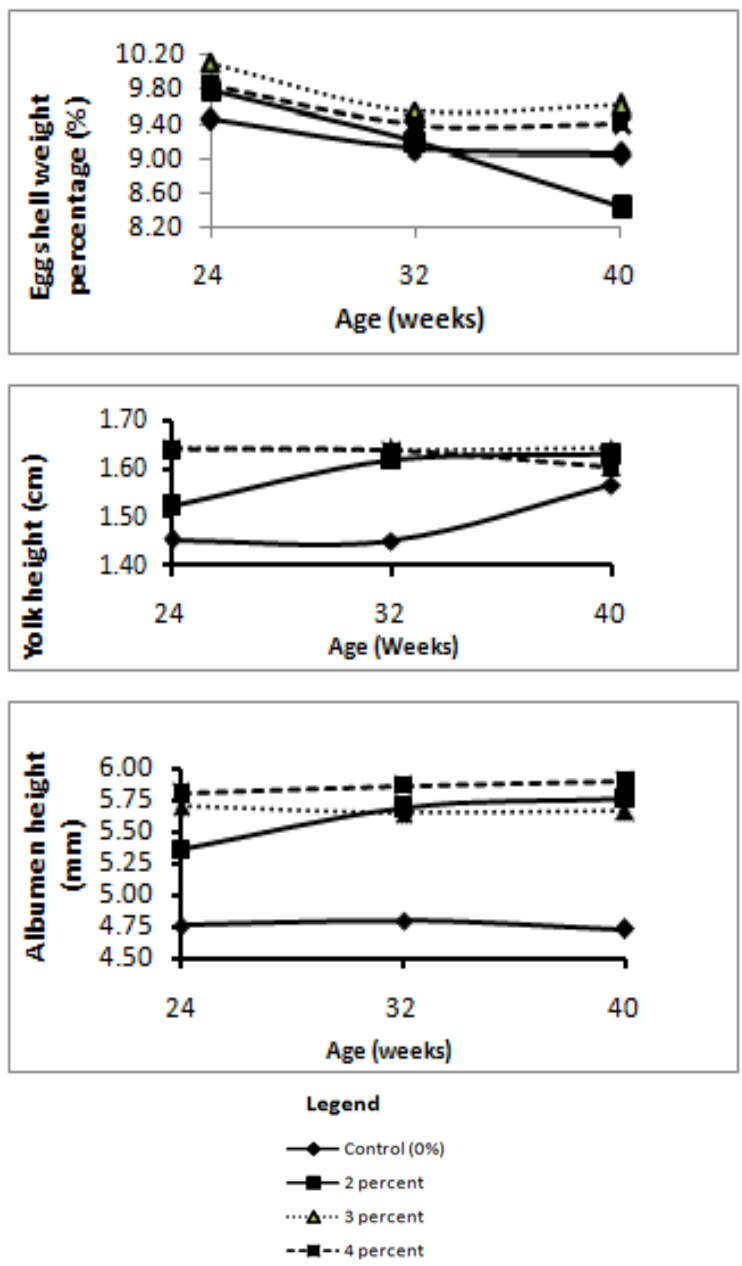

Fig. 3. Effect of dietary diatomaceous earth on eggshell weight percentage, yolk height and albumen height in deep litter raised hens.
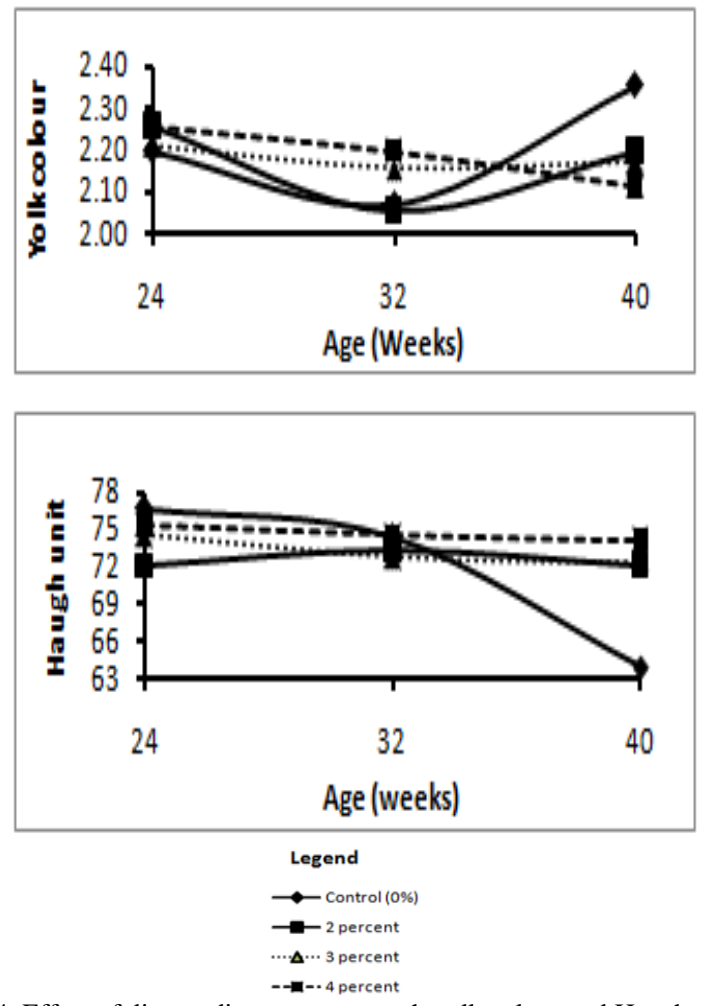

Fig. 4. Effect of dietary diatomaceous earth yolk colour and Haugh unit in deep litter raised hens.

\section{DISCUSSION}

Information regarding studies on effect of DE on egg quality parameters is still scanty. The significant $(\mathrm{p}<0.05)$ increase in egg weight with increasing hen age in all treatment groups as evidenced in this study is in line with findings of other previous studies [30]-[33]. Although not significant ( $>0.05$ ) at weeks 24 and 40 of age, the higher eggshell thickness observed in hens in intervention groups as compared to control groups in this study could be an indication that calcium absorption and utilization was higher in birds fed on DE supplemented diets. Eggs having thick and strong shells usually command a higher market elsewhere as compared to those with thin shells [34]. This trait is of high economic importance since thick shells protect the eggs from breakage. The higher shell weight observed in weeks 32 and 40 of age might be attributed to the fact that mineralized eggshell is formed of calcium carbonate (96\%); the remaining components include organic matrix (2\%), magnesium, phosphorus, and a variety of trace elements [35]. On the other hand, diatomaceous earth (diatomite) contains many minerals which include calcium, phosphorus, magnesium, silicon and many others as well as a range of trace elements which include iron, zinc, cobalt, potassium, manganese, molybdenum and sulphur [36]. Therefore, DE supplemented diet in this study provided more calcium and other trace elements required in eggshell formation. The yolk height of intervention groups was higher $(\mathrm{p}<0.05)$ than in control group. A significant $(p<0.05)$ increase in yolk height was observed throughout the entire duration of this study. This increase in yolk height might as a result of the mineral and trace elements present in DE (ibid).

The findings of this study showed clearly that supplementation of the hen diets with DE to levels above 3\% had no significant $(\mathrm{p}>0.05)$ effect on eggshell quality. This explains the absence of a significant increase in shell weight and shell thickness between hens fed 3\% and 4\% DE in their diets at week 40 of age. The significant increase in shell weight and shell thickness between hens given control diet and those on $1 \%$ and $2 \%$ DE supplementation at week 40 of age is in agreement with a study by [37]. In their study, they observed that increasing $\mathrm{Ca}$ level in diet beyond 3.6-3.8\% had no added beneficial effect on eggshell quality. The results of this study also depict that the significant $(\mathrm{p}<0.005)$ increase in yolk as well as in albumen heights was observed in week 40 of age as compared to weeks 24 and 32.

Basing on this finding, it can be suggested that DE supplementation plays a more significant role in improving egg quality especially by improving viscosity as flocks grow older as compared to younger flocks. This is evidenced by the higher yolk and albumen heights in week 40 seen in intervention group as compared to control group. This finding is in agreement with results got by another author who found out that older birds required more minerals especially calcium and phosphorus than younger ones for bone and egg mineral deposition [38].

Additionally, the significant $(\mathrm{p}<0.005)$ increase in yolk as well as in albumen height observed in week 40 in DE 
supplemented groups as compared to weeks 24 and 32 depicts that DE supplementation plays a more significant role in improving viscosity in as flocks grow older as compared to younger ones. The lack of influence on yolk colour in DE supplemented groups as compared to control groups evidenced in this study are suggestive that no interactions exist between DE supplementation and yolk colour score in deep litter raised hens.

\section{CONCLUSION}

The study showed clearly that dietary supplementation of different levels of diatomaceous earth in deep litter raised laying hens diet resulted into significant increase in egg shell weight and yolk height, thus, dietary diatomaceous earth supplementation can promote laying hen performance by improving those egg quality traits in deep litter raised hens. The DE in the current study was however not effective on other egg quality parameters such as eggshell weight percentage, egg specific gravity, yolk colour and Haugh unit. Additionally, DE supplementation plays a more significant role in improving egg quality especially by improving viscosity as flocks grow older as compared to younger flocks. Further research should focus on the effect of dietary diatomaceous earth on eggshell and bone strength of layer birds. More research should also explore the interactions among the mineral found in diatomaceous earth (e.g. calcium, phosphorus, and magnesium) and how these interactions affect product quality.

\section{ACKNOWLEDGMENTS}

The authors are grateful to The World Bank who through the National Agricultural Research Organization Competitive Grant Scheme (NARO-CGS Cohort III) (Grant Number CGS/2/12/14) funded the study.

\section{REFERENCES}

[1] Fields, P.G. (2000). Diatomaceous earth: Advantages and limitations. In: Proc. VII International Working Conference on Stored-Product Protection. Sichuan Publishing House of Science and Technology, Chengdu, China 1:781-784.

[2] McLean, B., Frost, D., Evans, E., Clarke, A. \& Griffiths, B. (2005). The inclusion of diatomaceous earth in the diet of grazing ruminants and its effect on gastrointestinal parasite burdens. International Scientific Conference in Organic Agriculture, pp 277 - 280. Adelaide, Australia. International Society of Organic Agriculture Research, Bonn, Germany.

[3] Kabak, B., Dobson, A.D.W., \& Var, I. (2006). Strategies to prevent mycotoxin contamination of food and animal feed: A review. Crit. Rev. Food Sci. Nutr., 46: 593-619.

[4] Berg, C. (2001). Health and Welfare in organic poultry production. ACTa Vet Scand. Suppl. 95:37.

[5] Bejaei, M. \& Cheng, K.M. (2010). Effects of demographic characteristics and attitudes of consumers on table egg consumption. Poult.Sci: 89 Suppl. (1): $644-645$.

[6] Bunch, T.R., Bond, C., Buhl K. \& Stone, D. (2013). Diatomaceous Earth General Fact Sheet; National Pesticide Information Center, Oregon State University Extension Services. http://npic.orst.edu/factsheets/degen.html (Accessed on August 23, 2019).

[7] Olusegun, O., Ikusika, C., Mpendulo, T., Titus, J.Z. \& Anthony, I.O. (2019). Fossil Shell Flour in Livestock Production: A Review. MDPI,
Basel, Switzerland. http://creativecommons.org/licenses/by/4.0/ (Accessed on August 21, 2019).

[8] Hamilton, R.M.G., Hollands K.G., Voisey, P.W. \& Grunder, A.A. (1979). Relationship between eggshell quality and shell breakage and factors that affect shell breakage in the field -a review. World Poult. Sci J. 35:177-190.

[9] Washburn, K.W. (1982). Incidence, cause, and prevention of eggshell breakage in commercial production. Poultry Science, 61, 205-2012.

[10] Roland, Sr. D.A. (1988). Research note: egg shell problems: estimates of incidence and economic impact. Poultry Science, 67, 1801-1803.

[11] Ahmed, N. M., Abdel Atti, K.A., Elamin, K.M., Dafalla, K.Y., Malik, H.E.E. \&Dousa, B.M. 2013. Effect of dietary calcium sources on laying hens performance and egg quality. J. Anim. Prod. Adv. 3:226-23[1].

[12] Sreenivas, D., Prakash, M.G., Mahendra, M. and Chatterjee, R.N. (2013). Genetic analysis of egg quality traits in white leghorn chicken. Vet. World, 6(5): 263-266.

[13] De Ketelaere, B., Govaerts, T., Coucke, P., Dewil, E., Visscher, J., Decuypere, E, \& De Baerdemaeker, J. (2002): Measuring the eggshell strength of 6 different genetic strains of laying hens: techniques and comparisons. British Poultry Science, 43, 238-244.

[14] Swiatkiewicz, S. \& Koreleski, J. (2008): The effect of zinc and manganese source in the diet for laying hens on eggshell and bones quality. Veterinary Medicine, 53,555-563.

[15] Nys, V. (2001): Recent developments in layer nutrition for optimizing shell quality. In: Proceedings of 13th European Symposium of Poultry Nutrition. Blankenberge, Belgium, 45-52.

[16] Kriz L 1997: Processing and treatment of poultry products. Mze ČR, Praha, Czech Republic, 29p.

[17] Lomakina, K. \&Mikova, K. 2006: A study of the factors affecting the foaming properties of egg white - A review. Czech J Food Sci24: 110118.

[18] Simeonovova, J., Mikova, K., Ingr, I. \&Kubisova, S. 2003: Technology of poultry, eggs, and minor animal products (in Czech). MZLU Brno, Brno, Czech Republic, 247p.

[19] Haugh, R.R. (1937). The Haughunit for measuring egg quality. US Egg. Poult. Mag. 43, 572-573.

[20] Jeffrey, K. (2010). "Organic Eggs: More Expensive, but No Healthier". Time magazine. Accessed July 21, 2019.

[21] Monira, K.N., Salahuddin M. \&Miah, G. (2003). Effect of Breed and Holding Period on Egg Quality Characteristics of Chicken. International journal of Poultry Science, 2 (4): 261-263.

[22] Wikipedia, The free encyclopedia. Downloaded on July 28, 2019.

[23] Skrivan, M., Englmaierová, M., Skrivanová, E. \& Bubancová, I. (2015). Increase in lutein and zeaxanthin content in the eggs of hens fed marigold flower extract. Czech J Anim Sci. 60:89-96.

[24] A.O.A.C. Official Methods of Analysis of AOAC INTERNATIONAL (2016) 20th Ed., AOAC INTERNATIONAL, Rockville, MD, USA, Official Method 2008.01.

[25] Isabirye, R.A., Waiswa, C., Kabi, F., Nanyeenya, N.W., Biryomumaisho, S., Acai-Okwee, J., Okello, S., Akello, B.O., Mwesigwa, M., Lumu, R. \&Nasinyama, G.W. (2019 $)$. Diatomaceous earth usage in the agriculture sector in Uganda and its characterization: Current status and anticipated developments. J. of Agric. Science and Food Technol. 5(4): 87-95.

[26] Sun, C. J., Chen, S.R., Xu, G.Y., Liu, X.M. \& Yang, N. (2012). Global variation and uniformity of eggshell thickness for chicken eggs. Poultry Science 91:2718-2721 http://dx.doi.org/10.3382/ps.2012-02220 (Accessed August 21, 2019).

[27] Valkonen, E., Venalainen, E., Rossow, L. \&Valaja, J. (2008). Effects of dietary energy content on the performance of laying hens in furnished and conventional cages. Poultry Science 87:844-852.

[28] Beardsworth, P.M.\&Hernandes, J.M. (2004): Yolk colour - an important egg quality attribute. International Poultry Production, 12 (5): $17-18$.

[29] SAS (2011). SAS Institute Inc. 201[1] Base SAS 9.3 Procedures Guide: Statistical Procedures. Cary, NC, USA.

[30] Guesdon, V.\& Faure, J.M. (2004). Laying performance and egg quality in hens kept in standard or furnished cages. Animal Research 53, 45-57.

[31] Roberts, J.R. \& Ball, W. (2006). Egg and eggshell quality guidelines for the Australian egg industry. In 'The amazing egg: nature's perfect functional food for health promotion'. (Eds By Sim J.S., Sunwoo H.H.) pp. 499-508. (Department of Agricultural, Food and Nutritional Science, University of Alberta: Edmonton). 
[32] Tumova, E. \&Ledvinka, Z. (2009). The effect of time of oviposition and age on egg weight, egg components weight and eggshell quality. Archiv fur Geflugelkunde, 73, 110-115.

[33] Roberts J. R, Kapil Chousalkar B and Samiullah A (2013). Egg quality and age of laying hens: implications for product safety. Animal Production Science, 2013, 53, 1291-1297 http://dx.doi.org/10.1071/AN12345.

[34] Melesse, A., Maak, S., \& von Lengerken, G. (2010). Effect of long-term heat stress on egg quality traits of Ethiopian naked neck chickens and their F1 crosses with Lohmann White and New Hampshire chicken breeds. Livestock Research for Rural Development. Vol. 22, Article \# 7[1]http://www.lrrd.org/irrd22/4/mele2207[1]htm. Accessed on August 23, 2019.

[35] Nys, V., Gautron, J., Garcia-Ruiz J.M. \& Hincke M.T. (2004): Avian eggshell mineralization: biochemical and functional characterization of matrix proteins. ComptesRendusPalevol, 3, 549-562.

[36] Isabirye, R.A., Waiswa, C., Kabi, F., Nanyeenya, N.W., Biryomumaisho, S., Acai-Okwee, J., Okello, S., Akello, B.O., Mwesigwa, M., Lumu, R. \& Nasinyama, G.W. (2019²). Efficacy of diatomaceous earth on Ascaridia galli, blood parameters and on ectoparasites in chicken.

[37] Koreleski J., Swiatkiewicz S. (2004): Calcium from limestone meal and grit in laying hen diets - effect on performance, eggshell and bone quality. Journal of Animal and Feed Science, 13, 635-645.

[38] Costa et al, 2010. Costa C.H.R., Barreto S.L.T., Umigi R.T., Lima H.J.D., Araújo M.S., Medina P. (2010). Balance of calcium and phosphorus and study of these minerals in diets for Japanese quails (from 45 to 57 weeks of age). Revista Brasileira de Zootecnia. 38 (8): 1748-1755. 